\title{
Job Satisfaction among Male and Female Teachers in Faridabad
}

\author{
Dr. Kanchan Jamir ${ }^{1} *$
}

\section{ABSTRACT}

The aim of this research paper is to find out job satisfaction among male and female teachers in Faridabad schools. Total number of 100 teachers was assigned in two groups of male and female teachers in primary and senior sections. A survey type study was designed to find out the job satisfaction and occupational stress among teachers. In this study the tool was used Job Satisfaction Scale (J.S.S) by Dr. Amar Singh and Dr. D. R. Sharma. Data was treated by Mean, $\mathrm{SD}$, and T-Test. The finding of the study revealed that there was a significant difference among teachers in their job satisfaction and occupational stress.

Keywords: Job-Satisfaction, Occupational stress.

Job satisfaction is a positive feeling and thinking about one's job. It includes the feelings about all the different terms related to the job like timings, working hours, salary and earnings, work environment, coworker's behavior etc. The concept of job satisfaction has been studied and developed by different researchers. One of the most widely used definitions in organizational research is that of Locke (1976), who defines job satisfaction as "a pleasurable or positive emotional state resulting from the appraisal of one's job or job experiences." Locke and Lathan (1976) define job satisfaction as a pleasurable or positive emotional state resulting from the appraisal of one's job or job experience. Job satisfaction is a result of employee's perception of how well their job provides those things that are viewed as important.

An employee might be satisfied with one aspect and be dissatisfied with another aspect. For instance, someone may be very satisfied with the timings and coworker's behavior, but his salary may not satisfy him. His reaction in this situation depends on the importance of each aspect for him and the overall satisfaction of his job. Hulin, C. L., \& Judge, T. A. (2003) believe it is not as simplistic as this definition suggests and instead that multidimensional psychological responses to one's job are involved.

\footnotetext{
${ }^{1}$ Asst. Prof. Dept. Of Psychology, Pt. Jawaharlal Nehru College, Faridabad, Haryana, India *Responding Author

(C) 2016 I K Jamir; licensee IJIP. This is an Open Access Research distributed under the terms of the Creative Commons Attribution License (http://creativecommons.org/licenses/by/2.0), which permits unrestricted use, distribution, and reproduction in any Medium, provided the original work is properly cited.
} 


\section{Job Satisfaction among Male and Female Teachers in Faridabad}

According to (Mitchell and Lasan, 1987), job satisfaction is the most important and frequently studied attitude. Luthan (1998) revealed three important dimensions to job satisfaction:

- Job satisfaction is an emotional response to a job situation.

- Job satisfaction is determined by how well outcome meet. For example, if the workers feel that they are working harder than others but are receiving very less they will have negative attitudes towards the work, but if they feel they are being treated very well and are being paid nicely, they will have positive attitudes towards their job.

- Job satisfaction represents several related attitudes which are most important Characteristics of a job about which people have effective response like: the work itself, pay, promotion opportunities, supervision and coworkers.

According to Smith et al. (1975), job satisfaction means "the perceived characteristics of the job in relation to an individual's frames of reference. Alternatives available in given situations, expectations, and experience play important roles in providing the relevant frame of reference". Brief and Weiss (2001) defined job satisfaction as "a pleasurable emotional state resulting from the evaluation from performance". Robert Dailey (2003) in his book mentioned job satisfaction as "a function of employee perceptions of events at work". He classifies job satisfaction in five groups, "1) satisfaction with the work itself, 2) satisfaction with pay, 3) satisfaction with fellow workers, 4) satisfaction with supervision and 5) satisfactions with promotions".

Job satisfaction is very important because it affects one's performance and productivity. It affects an individual's experience of work or quality of working life, general well-being, stress at work and out of work life, working conditions and the home environment.

Job satisfaction does not only depend on the quality of the employment, but also on the worker's expectations with respect to the job. Job satisfaction is so important that its absence often leads to reduced organizational commitment (Levinson, 1997, Moser, 1997). Lack of job satisfaction is a predictor of quitting a job (Alexander, Hellmann, 1997; Jamal, 1997).

\section{Objectives}

1. To find out significant difference in job satisfaction among male and female teachers in Faridabad schools.

\section{Hypotheses}

1. The poor salary structure makes both the male and female teachers dissatisfied with this profession.

2. With regard to the working environment the female teachers are more dissatisfied than their male counterparts.

3. There would be significant difference in job satisfaction among male and female teachers. 


\section{METHOD}

\section{Sample}

The purposive sample comprised all the available working teachers in different schools. Total number of 100 teachers was assigned to two groups of male and female teachers in primary and senior sections.

\section{Tools}

For this purpose the following tool was used:

Job Satisfaction Scale (JSS): The job satisfaction scale is developed by Dr. Amar Singh and Dr. D. R. Sharma. The scale compares favorably with Muthayya's job satisfaction questionnaire giving a validity coefficient of .743. The scale measures job satisfaction in two types of areas job-intrinsic (factors lying in the job itself) and job-extrinsic (factors lying outside the job). These areas are covered in 30 statements. Each statement had five alternatives from which a respondent had to choose any one which candidly expressed his response. Q. No. 6, 11, 13, 19, 23 and 25 had job concrete statements whereas job-abstract statements were in the form of Q.No. 8, 15, 16, 17, 21 and 27. Job extrinsic statements found their place in Q.No. 1, 3, 4, 7, 10, 12, 26 and 30. Economic and community growth statements were numbered as 2, 5, 9, 18 and 14, 22, 24, 28 and 29.

\section{RESULTS AND DISCUSSION}

Table 1 (Female Teachers 'Job Satisfaction Score)

\begin{tabular}{|l|l|l|l|}
\hline & INTRINSIC & EXTRINSIC & TOTAL \\
\cline { 2 - 3 } & SATISFACTION & SATISFACTION & SATISFACTION \\
\hline S.D & 32.26 & 45.1 & 77.36 \\
\hline T-Score & 3.92 & 7.40 & 9.88 \\
\hline
\end{tabular}

Table 1 is showing the Mean , S.D and T-Score of the of female teachers job satisfaction on their intrinsic , extrinsic and total satisfaction, which reveals that the Mean of intrinsic and extrinsic satisfaction is 32.26 and 45.1 so the total satisfaction score is 77.36 whereas the S.D value of these factors are 3.92, 7.40 and 9.88 . We can see the T-Score of the total satisfaction of female teachers according to the given table is -1.30 which reveals less job satisfaction in female school teachers.

In 1968 Frederick Herzberg stated that satisfaction and dissatisfaction are caused by various factors-motivation and hygiene factors. Motivating factors of the job are those aspects of the job that encourage people to work and make them satisfied. These factors are intrinsic and depend on the nature of the job. Hygiene factors include working conditions such as policies of the organization, payroll system. He was the first one who introduced job satisfaction spectrum and 


\section{Job Satisfaction among Male and Female Teachers in Faridabad}

noted that if someone doesn't have dissatisfaction feelings about his job, it doesn't necessarily mean that he is satisfied with his job. Maybe he is indifferent to his job.

Many theorists have tried to come up with an explanation for why people feel the way they do in regards to their job. Locke developed the idea known as discrepancy theory. This theory suggests that a person's job satisfaction comes from what they feel is important rather than the fulfillment or unfulfillment of their needs. A person's importance rating of a variable is referred to "how much" of something is wanted. Discrepancy theory suggests that dissatisfaction will occur when a person receives less than what they want (Berry, 1997).

Table 2 (Male Teachers 'Job Satisfaction Score)

\begin{tabular}{|l|l|l|l|}
\hline & $\begin{array}{l}\text { INTRINSIC } \\
\text { SATISFACTION }\end{array}$ & $\begin{array}{l}\text { EXTRINSIC } \\
\text { SATISFACTION }\end{array}$ & $\begin{array}{l}\text { TOTAL } \\
\text { SATISFACTION }\end{array}$ \\
\hline Mean & 34.22 & 46.86 & 81.08 \\
\hline S.D & 5.05 & 7.27 & 10.76 \\
\hline T-Score & - & -12.64 & 1.17 \\
\hline
\end{tabular}

Table 2 is showing the Mean, S.D and T-Score of the of male teachers job satisfaction on their intrinsic, extrinsic and total satisfaction, which reveals that the Mean of intrinsic and extrinsic satisfaction is 34.22 and 46.86 so the total satisfaction score is 81.08 whereas the S.D value of these factors are 5.05, 7.27 and 10.76 . We can see the T-Score of the total satisfaction of male school teachers according to the given table is 1.17.

According to Lisa (2008) "conflict between work and family was found to be a factor in many family problems such as depression, alcohol use and job satisfaction.” According to Maike et al (2010)"'Time is such a scarce source, flexible arrangements are a top indicator of work life equality and employee satisfaction."

Iqbal \& Akhtar (2012) compared the level of job satisfaction between male and female secondary school teachers in all public sector secondary school teachers working in district Lahore, Pakistan. Data analysis results showed that Female teachers were more satisfied with work and supervision aspects of job as compared with male teachers and also there is no significant difference in the job satisfaction between science \& arts and urban \& rural school teachers.

\section{Acknowledgments}

The author appreciates all those who participated in the study and helped to facilitate the research process.

\section{Conflict of Interests}

The author declared no conflict of interests.

(c) The International Journal of Indian Psychology, ISSN 2348-5396 (e)| ISSN: 2349-3429 (p) | 46 


\section{REFERENCES}

Berry, Lilly M. (1997). Psychology at work. San Francisco: McGrow Hill Companies Inc.

Brief, A. P. Weiss, H. M.(2002). "Organizational behavior: Affect in the workplace”. Annual Review of Psychology 53:279-307. doi: 10. 1146/annurev.psych.53.100901.135156.PMID 11752487.

Hulin, C. L., \& Judge, T. A. (2003). Job attitUdes. In W. C. Borman, D. R. ligen, \& R. J. Klimoski (Eds.), Handbook of psychology: Industrial and organizational psychology (pp. 255-276). Hoboken, NJ: Wiley.

Iqbal, D. A., \& Akhtar, D. S. (2012). Job Satisfaction of Secondary School Teachers. Abasyn Journal of Social Sciences, 5 (1).

Lisa, A. (2008). Factors that affect job satisfaction among teachers in two selected Milwaukee charter schools. pp20.(master thesis, Capella University. School of Human Services).

Locke,E.A.,1976.The nature and causes of job satisfaction. In: Dunette, M.D.(Ed.),Handbook of Industrial and Organizational Psychology(pp.1297-1349). Chicago: Rand McNally.

Smith, P. C., Kendall, L. M.,\& Hulin, C.L.(1969) The measurement of satisfaction in work and retirement. Chicago: Rand McNally.

Spector, P.E. (1997). Job satisfaction: Application, Assessment, Causes and Consequences. Sage, London.

How to cite this article: K Jamir (2016), Job Satisfaction among Male and Female Teachers in Faridabad, International Journal of Indian Psychology, Volume 3, Issue 4, No. 60, ISSN 23485396 (e), ISSN: 2349-3429 (p), DIP: 18.01.081/20160304, ISBN: 978-1-365-26308-8 